\title{
ANNOUNCEMENT-ANNOTATION TEXTS: DEFINITION, CORRELATION AND SYNTHESIS
}

\author{
Olga Dzykovych \\ National Technical University of Ukraine "Igor Sikorsky Kyiv Polytechnic Institute”, Kyiv, Ukraine \\ dzykovych@gmail.com
}

\author{
Sandra J. Langer \\ University of Siegen, Siegen, Germany \\ lesen.bildet@gmx.de
}

\begin{abstract}
The paper deals with the problems of definition, correlation and synthesis of two text types: announcement and annotation. The main goal of this article is to postulate they have enough similar features to be combined in one text type. The examination of the relationship between different types of text is one of the most current research topics in the European linguistic literature, to which more and more studies draw the attention. However, the empirical research is still rarely carried out. In this paper, announcement and annotation have been examined on common and different features of both speech genres with a view to a correlation of these genres. After the synthesis of two text types, the authors determined their common traits which evidence these genres consistency. After all, the suggestion was made to integrate the definitions of announcement and annotation texts into one definition: announcementannotation texts (or annotexts). Although this postulate needs to be modified and supplemented in view of text types selected for analysis, it is a good starting point for further research.
\end{abstract}

Keywords: text types; genre; small-format text; announcement; annotation; annotext; relationships between text types.

\section{Introduction}

Nowadays small-format texts (SFTs) (small sized texts, mini texts, short texts) have become one of the most available and popular sources of information. SFTs demonstrate the following features: small volume, informativeness, laconic brevity and linguistic means compression. According to Lomonosova's classification, SFTs are introduced in different types: announcements, summaries, posters, a quick round of questions, notes, internet miniatures, comments, abstracts, mini stories, mini reviews, minirecommendations, mini critical reviews, press releases, advertising texts, goods description texts etc. Each type of the text represents its functional focus, linguistic features, and structure (Lomonosova, 2015, p. 2).

By contrast with full sized texts, SFTs are of short volume, exhibit compressed information and issuerelated consistency (the expression of one fact, event or phenomenon). The point of dispute is the SFT volume. Some researchers consider that such type of text should comprise from one to seven sentences (phrases) (Tolstolutskaya, 2008, p. 66). Others suggest the volume within a conventional printed sheet (Panchenko, 2013, p. 213) or 60 newspaper lines (Nechaev, 1997, p. 46). English linguists deem and consider the SFT volume should be 300-500 or maximum 1500 words (Pratt, 1981), Russian linguists set down the volume from 25 till 650 words (Plotnikova, 2012). Due to the Internet operation intensification, scientists are prone to discuss the SFT in a size within "one screen" (while reading on a display we do not need to scroll the page) (Plotnikova, 2012, p. 23).

The fundamental study of all SFT types has not been presented either by Ukrainian, Russian or European linguists. A great number of authors describe the characteristics of one or two SFT types. Researchers have not arrived at the common conception for SFT genres diversity and they even sometimes contradict one another. To some extent, SFTs were studied in research papers on journalistic essays genre types (Tertychnyi, 2000; Mantulo, 2011; Vasylenko, 2006). The objective of our paper is the focus on SFT in a system of speech genres. The classification of the essays is not unique. Some researchers stand out SFT as such independent genres as: informative (announcement, chronics, remark, summary, mini- review, miniobservation, mini-portrait etc.) (Lavryk, 2008; Tertychnyi, 2000); fiction -public (announcement, citation, review) (Ivashchuk, 2007). Others consider these texts as not independent genre since "their features are shown up only through the connection with other genres" (title, comment) (Miasnikov, 2006); or such texts are proved to be established genres as notes variety (Tertychnyi, 2000). Therefore, we often find such texts as an announcement, event posters or advertising announcement/description among published advertising genre (Sokolova, 2008; Panchenko, 2013). 


\section{Objective and targets of the study}

The emerging interest to SFT is substantiated by the internal tension of an utterance but not by the genre diversity. The syntactic and lexical structure of SFT is developed by the presence of two opposite features: formal laconism vs context fullness; stereotype vs creativity. Such contradiction diversifies SFT speech patterns and, therefore, make them a challenging research subject due to the fact that the expressiveness and semantic compression, owing to a conflict, are seen on all levels in SFT from morphological to phraseological ones (Dzykovych, 2016, p. 580).

With this in mind, we consider SFT of announcements and annotations as an interesting corpus since these types explicit their consistency almost on all stages of formation and functioning. So that to confirm the statement about the consistency of these two speech genres and the combination of them into the term "announcement-annotation texts", we suggest the first stage of the research and correlation of these texts types: definition analysis and synthesis of the integrated term of an announcement and an annotation.

Consequently, in order to achieve our goal and to accept the hypothesis, we have defined the following targets:

- to carry out a complex study of an announcement and annotation definitions as SFT;

- to suggest our definition;

- to compare the definitions;

- to confirm their consistency by integrating their notions.

\section{Definition}

There is a great number of announcement definitions. According to the commonly used definition, an announcement is an annunciation of any event (concert, exhibition, film, book or software release). An announcement can be represented as an event poster, media article or TV/ radio announcement (Nekrasov, 2009, p. 172). Hylko (2000) considers the announcement as the submission of compressed and succinct information about the audio-visual art piece, its plot, content and artistic value (p. 23). In conformity with German dictionary, (Kunkel-Razum \& Münzberg, (Eds.), 2009), an announcement is a preview of different events, theatre, cinema, radio and TV programs with a short review of the event. By Lashchuk (2004), an announcement is a preventive message of upcoming events that take place in different areas of public life: briefings, meetings and official visits, performances, concerts etc. The prime purpose of the announcement is to give objective information on time and the content of the event, on the most important preconditions and phases of the event (p. 75). Lavryk (2008) states that the announcement is a brief or extended message about an event that should happen soon (p. 24).

Ahmadayeva (2007) develops a deeper understanding of an issue as she takes into account the audience. Thus, by linguist interpreting, the announcement is the text about a fiction film, performance, public event, with a view to reporting the data of the event and presents them as a grand event to form the public's good opinion about it through various media distributions (p. 7).

It is an interesting fact, that announcement genre can be called a general journalistic, as by operating speech patterns, it can be observed in every journalistic genre (periodic, TV, radio, Internet etc.). However, it should be noted that some researchers consider announcement as a type of informative note (Smelkova, 2004; Tertychnyi, 2000). Ivashchuk (2007) claims that emphatics and unambiguity of such definition are controversial. Certainly, a note can be an announcement and it is widely used in our modern media. As a rule, such announcements are placed at the beginning or ending of the issue. But, can they be called notes? According to all characteristics, an announcement corresponds the fiction public genre as it demonstrates the features of the genre and creative thinking. Metaphor, vivid associations, comparisons are frequently used in internet or TV announcements and these literature characteristics are not intrinsic for a newspaper style. Moreover, announcement extends its boundaries through social globalisation, culture integration and informative boom. Taking into consideration these facts, it should be stated that an announcement is an independent informative genre (Ivashchuk, 2007).

Kovalchukova (2008) also specifies the announcement as an independent genre, which corresponds Bakhtin's genre model (p. 55).

Thus, summing up the presented definitions, we will try to colligate the announcement definition considering pragmatic aspect. Based on existing definitions, an announcement is a small format text, the intention of which is concise, semantically compressed, objective notification of an event or phenomenon or personal presentation with the purpose to inform, to form an evaluation and attract potential recipient to the interaction by a special selection of speech patterns and text organisation.

The annotation (abstract) genre is also a type of SFT. It is a short, compressed text which refers to general informative genres and small format critic genre as well. General features of this text are conditioned 
by the need to create and widespread the abstracts in practice that follows the continuous growth of information and intensive communication. The annotation communicative purpose is to inform the recipient about the contents of articles, studies, books, speeches, documents, etc. by providing the information of a generalised nature. An abstract presentation object is an informational event (books, articles publishing etc.) that was held or is planned and is affordable for a wide range of people.

An annotation (or abstract) (Lat. anotation) is a special kind of oral or written information, which is available for fixed positions or a brief description of the contents of books, articles, manuscripts, i.e. it is the maximum reduced amount of information sources (Gorodetska, 2013, p. 674). The annotation briefly presents the content of the informative product that allows understanding its meaning, organisation and problematic issues. The annotation is a brief description of the content, purpose, form, function and other features of oral or published utterance. As a rule, it includes a little amount of information about the content and benefits of the paper, and thus, discloses its pragmatic and axiological potential. An annotation should contain the novelty comparing with previous papers, articles, books with the similar topic or purpose. It also includes essay type characteristics, main themes, issues and goals (Anisimova, 2011, p. 7).

Shulinova (2010) describes an annotation as short, brief characteristics of a book, an article or a manuscript. Thus, the annotation is a short characteristic of above essays, contains the list of main chapters, themes or issues. Although it is interesting, that according to this definition, an annotation can not only inform about the content but evaluate the essay, information about an author, writing history, references, advertise the product and propagate knowledge about it. Conditionally, abstract should answer the questions: What is it about? How? What parts? Who? (p. 378). More amplified definition with the pragmatic and evaluating aspect is suggested by Pervuhina (2012). She claims that annotation comprises the maximal compression of input material. The annotation is a secondary text with the extremely succinct content. It is short, includes main content aspects, aimed at the reader attraction and to motivate him/her to perception and cognition of an original product. These texts are characterised not only by content compression but by author's evaluation and emotions (p. 42).

According to Bugrova (2012), the definition of annotation has pragmatic focus. So, the researcher states that annotation is a written or oral utterance which is created with the aim to convince the receiver or to form his/her opinion. The main task of an annotation is to attract recipient's attention by means of speech forms. Bugrova (2012) defined the differentiated features of an abstract as a speech genre:

- concise description of statements;

- pragmatics (target orientation of a text);

- polyhistory (information about an author and his/her other essays) (p. 18).

It is obvious that intentionality and the utterance purpose are predominant in annotations, it evidences the recipient orientation of annotations.

Despite the annotation definition made by DIN which claims that an annotation is the compressed meaning communication of a scientific paper without interpretation and evaluation, European researchers develop this notion from another point of view. By Stock and Stock (2008), an annotation is an interpreted content of output text, semantically compressed and aimed at much amount of the information communication in the shortest way for the fast and clear perception (p. 77). Genette (2001) allocates the definition with a priority of recipient's attention attraction and his/her focusing on key points (from an author's point of view). It should be stated that the prime focus of a definition varies with an abstract type. However, in general, the main common features are pragmatics, address and evaluation criteria of the genre.

Thus, while the developing our own definition, we take into consideration pragmatics and consider an annotation as a secondary text which translates the content of an existing or potential product of any form (written or oral) in a compressed way; an annotation is oriented to wide range of recipients (taking into account possible narrow focus of an original text), it is characterised by main product parameters; an annotation has the organised speech, that demonstrates the main author's aspects which should be maximally accepted by a recipient through the simplest from and shortest time period.

\section{Correlation}

On the condition of such complex approach to these definitions, it is reasonable to examine common and different features of both speech genres with a view to a correlation of the genres. Main differences are annotation secondariness and absence of time reference comparing with an announcement. An announcement is an original product since it is composed to advertise an event or product. On the other hand, if a book is advertised, its annotation or abstract description (Buchankündigung) will serve functions of both genres and demonstrate the features of an annotation and an announcement as well. And in contrast, an announcement is a secondary text as it has been written on the basis of an existing text. Whereas TV 
products are taken much time before their broadcasting. It means that their announcement in newspapers or Internet pages demonstrates secondary features as it has been written on the basis of an existing product, however, it "announces" the future event. This contradiction of announcement chronotopus and abstract paratextuality creates challenging prerequisite for their studying comparing and integrating them.

\section{Synthesis}

The problem of different texts types' interconnection is the most relevant issue in the modern linguistics. It is a question of present interest especially in German philology since the controversial nature of the matter contributes to new scientific researches. Even on the condition of proper theoretical background, the complex and empirical studies on this issue are advanced in linguistics. It is substantiated by the fact that the texts type diffuseness is not a transcendental issue anymore. A great number of scientists have developed this concept in the beginning of the third millennium: Adamzik, 2000; Klein, 2000; Kraus, 2000; Holly, 2011; Janich, 2009; Heinemann, 1997; Rada, 2012; Gyuricza, 2015. The focus of their researches is the text types' interrelation.

Considering the objective of our paper, we will try to translate the earlier discussed issues on our targets. We have to find common traits of an annotation and an announcement and to integrate their notions into one definition.

In spite of these text definition differences, time and place convention and text primariness vs. secondaries, we have determined the common traits which evidence these genres consistency:

- functional informativity;

- succinctness, laconism and speech patterns compression;

- denotative meaning of the content;

- wide heterogeneous auditory orientation;

- targeting on recipient interaction;

- intentionality through expressed pragmatism;

- availability;

- chronotopicity;

- paratextuality.

Comparing our own definitions of an abstract and an announcement, correlating their common and distinctive characteristics, we suggest integrated definition of announcement-annotation text (AAT or annotext). In accordance with the generalised differentiated features stated above, announcement-annotation text is an event, product, person or time and place related small format text focused on qualitative information provision of wide range audience about the peculiarities of the event, product or person and aimed at knowledge objectification, evaluation and awareness formation about the event, product or person and creation of potential interaction. The most relevant examples of such texts are:

- television announcements of wide range programs and shows;

- advertising descriptions of existing or new products;

- books reviews for published and announced books;

- conferences, symposia workshops, concerts, performances announcements;

- call for papers;

- marriage advertisements;

- rent posts;

- products and services offers.

\section{Conclusions}

Announcement-annotation texts are one of the most affordable and the most popular sources of information, the construction and principles of which are of anthropologic and pragmatic nature. Explicability that is specific for the announcement-annotation texts provides us with the detailed information about the nature, purpose, form and content of AAT. However, the unexplored character of these texts combination the research of these phenomena is of promising outlook. The future areas of the AAT research may include structural and compositional features, typology, functioning and pragmatics.

\section{References:}

Adamzik, K. (2011). Textsortennetze [Text types networks]. Textsorten, Handlungsmuster, Oberflächen. Linguistische Typologien der Kommunikation, 367-385. https://doi.org/10.1515/9783110229301.367

Ahmadeeva, S.A. \& Vetohina J. G. (2007). Anons hudozhestvennogo fil'ma: zhanr, tipologija i jazykovye osobennosti v aspektah svjazej s obshhestvennost'ju, reklamy i zhurnalistiki [The announcement of the film: the genre, typology and language features in aspects of public relations, advertising and journalism]. Proceedings of the IVth Russian scientific and practical conference "PR-technologies in the information society", (pp. 7-16). Saint-Petersburg, Russia. 
Anisimova, E. I. (2011). Rekomendacii po oformleniju rukopisi [Recommendations on the manuscript]. Cheboksary, Russia: Chuvash. U.

Bugrova, E.D. (2012). Pragmaticheskie osobennosti annotacii [Pragmatic features of annotations]. Proceedings of the XIIIth International scientific and practical conference "Innovations in science", (pp. 11-22).

Dzykovych, O.V. (2016) "I'm searching for you" Marriage announcement. The descriptive linguistic search. Naukovi zapysky KDPU. Seriia: Filolohichni nauky, 145, 579-581.

Genette, G. (2001). Paratexte. Das Buch vom Beiwerk des Buches [The book about book annex]. Frankfurt/Main, Germany.

Gorodetska, V.A. (2013). Abstract as a kind of scientific text compression. Filolohichni studii, 9, 672-682.

Gyuricza, K. (2015). The linguistic research of relationships of the text types. Argumentum, 11, 64-81.

Heinemann, W. (1997). Zur Eingrenzung des Intertextualitätsbegriffs aus textlinguistischer Sicht [Intertextuality concept from a textlinguistic perspective]. Textbeziehungen. Linguistische und literaturwissenschaftliche Beiträge zur Intertextualität, 21-38.

Holly, W. (2011). Medien, Kommunikationsformen, Textsortenfamilien [Media, communication forms, text types families]. Textsorten, Handlungsmuster, Oberflächen. Linguistische Typologien der Kommunikation, 144-163. https://doi.org/10.1515/9783110229301.144

Hylko, N.F. (2000) Audiovizual'naja kul'tura [Audiovisual culture]. Omsk, Russia.

Ivashchuk, A.A. (2007). The interpretation of the note and fact genre in contemporary Ukrainian journalism. Naukovi zapysky Instytutu zhurnalistyky, 27, 113-115.

Janich, N. (2009). Zur Analyse von Textsorten-in-Vernetzung. Eine Modelldiskussion an einem Fallbeispiel aus der Unternehmenskommunikation [The analysis of the text types in relationships. A model discussion on a case from enterprise communication]. Essen, Germany: Laud.

Klein, J. (2000). Intertextualität, Geltungsmodus, Texthandlungsmuster [Intertextuality, modus operandi, text sample]. Textsorten. Reflexionen und Analysen, 31-44.

Kovalchukova M.A. (2008). The announcement as a speech genre (on the material of Internet discourse). Vestnik Cheljabinskogo gosudarstvennogo universiteta, 30, 54-57.

Krause, W.-D. (2000). Kommunikationslinguistische Aspekte der Textsortenbestimmung [Communication and linguistics perspective of text types determinations]. Textsorten. Kommunikationslinguistische und konfrontative Aspekte, 34-67.

Kunkel-Razum, K.\& Münzberg, F. (Eds.). (2009). Die Grammatik. Unentbehrlich für richtiges Deutsch. Mannheim; Wien; Zürich: Dudenverlag.

Lashchuk, O.P. (2004). Redaktirovanie informacionnyh soobshhenij [Editing information messages]. Moscow, Russia: Aspekt Press.

Lavryk, O.V. (2008). Osnovy zhurnalistyky [Fundamentals of journalism]. Kyiiv, Ukraine: KhNU im. V. N. Karazina.

Lomonosova, E.S. (2015) Genre features of small form texts. Universum: philologija i iskusstvovedenie, 17, 1-15.

Mantulo, N.B. (2011). Genre paradigm of mass communication discourse. Visnyk Dnipropetrovskoho universytetu. Seriia: Sotsialni komunikatsii, 11, 76-83.

Miasnikov, I.J. (2002). Zhanrovye osobennosti malyh tekstov SMI (lingvisticheskij aspekt) [Genre features of small media texts (linguistic aspect)]. Proceedings of the International conference "The language situation in Russia at the beginning of the XXI century”, (pp. 42-58). Kemerovo, Russia: KemGU.

Nechaev, K.A. (1997). Experience in the analysis of newspaper articles containing information on exchange activities. On the German press material. Slovo o dinamike, 45-53.

Nekrasov, B.V. (2009). Sredstva massovoj informacii dlja korennyh malochislennyh narodov. Instrumenty PR $v$ prodvizhenii obshestvennyh iniciativ [The media for indigenous peoples. PR tools for promotion of public initiatives]. Moscow, Russia: CS KMNS.

Panchenko, K.I. (2013). Linguistic features of small form texts. Naukovi zapysky Natsionalnoho universytetu "Ostrozka akademiia". Seriia: Filolohichna, 38, 213-218.

Pervuhina, S.V. (2012). Composite and pragmatic characteristics of annotations as a secondary texts. Izvestija Volgogradskogo gosudarstvennogo pedagogicheskogo universiteta. Sovremennaja teorija jazyka, 7, 40-51.

Plotnikova, A. A. (2012). The text volume of lyrical Internet-miniatures as a key feature of the genre. Vestnik Tomskogo gosudarstvennogo universiteta, 354, 23-26.

Pratt, M. (1981). The Short Story: The Long and the Short of It. Poetics, 10, 175-194.

Rada, R. (2013). „,Und man zieht aus diesem Bruch stilistischen Gewinn”. Stilistisch motivierte typologische Intertextualität in deutschen und ungarischen Gebrauchstexten [Stylistically motivated typological intertextuality in the German and Hungarian specifications]. Budapest, Hungary: ELTE Germanistisches Institut.

Shulinova, L.V. (2010). Abstract in the system of genres of scientific style in Ukrainian language. Movni $i$ kontseptualni kartyny svitu, 29, 377-381.

Smelkova, Z.S. (2004). Ritoricheskie osnovy zhurnalistiki. Rabota nad zhanrami gazety [Rhetorical foundations of journalism. Work on the newspaper genres]. Moscow, Russia: Flinta.

Sokolova I.V. (2008). Tekst-anons yak obiekt linhvistychnykh doslidzhen [Announcement text as an object of linguistic research] (Shvachko S.O., Ed.). Sumy, Ukraine: SumDU.

Stock, W.G. \& Stock, W. (2008) Wissensrepräsentation. Informationen auswerten und bereitstellen [The representations of knowledge. Information analyzing and giving]. Munich, Germany: Oldenbourg. https://doi.org/10.1524/9783486844900

Tertychnyi, A.A. (2000). Zhanry periodicheskoj pechati [Periodic press genres]. Moscow, Russia: Aspekt Press.

Tolstolutskaya, E.W. (2008). Structural and grammatical features of small-format text (French press). Zhurnal nauchny publikacij aspirantov i doktorantov, 6, 66-68.

Vasylenko, M.K. (2006). Dynamika rozvytku informatsiinykh ta analitychnykh zhanriv v ukrainskii presi [The development dynamics of information and analytical genres in Ukrainian press]. Kyiv, Ukraine. 